\title{
Bedensel Mim Ve Etienne Decroux
}

\author{
DüZenLeyen Ve ÇEviren \\ Nalan ÖZdemir
}

Bedensel Mim'im (Mime Corporel) kurucusu Etienne Decroux (1899-1991), Modern Mim'in Babası olarak nitelendirilir. Decroux'nun, "Belki de Doğulu tiyatro gelenekleriyle kıyaslanabilecek bir kurallar sistemi geliştirebilmiş tek Avrupalı usta" olduğuna inanan Eugenio Barba, Decroux'yu “Gizli Usta” olarak isimlendirir. Tiyatro kariyerine 1923 yılında Jacques Copeau'nun okulu Vieux Colombier'de başlayan Decroux 1926-1934 yılları arasında başta Charles Dullin, Louis Jouvet, Antonin Artaud ve Gaston Baty ile birlikte çok sayıda tiyatro oyunu ve filmde yer aldı; ancak 1931 yılında tanıştığı Jean-Louis Barrault ile birlikte temellerini attığı yeni bir tiyatro formu olan Bedensel Mim asıl çalışma alanı oldu. Decroux 1940 yılında Paris'te kendi okulunu açtı, bu okul 1980 'lerin ortalarına kadar mim dünyasının merkezlerinden biriydi.Théâtre de l'Atelier, Milano'daki Piccolo Teatro ve New York Üniversitesi'nde ders vermekle birlikte bedenin ifade olanakları üzerine "saf araştırması"nı yürüttüğü asıl mekan, Paris'teki evinin bodrum katındaki okulu olmuştur. Yıllar içinde dünyanın dört bir tarafından yüzlerce öğrenci buraya akın etti. Bu okul ismini bir ölçüye kadar Decroux'nun en ünlü öğrencisi Marcel Marceau sayesinde duyurmuştur. Oysa Marcel Marceau, tekniğini modern, kübist, öykü anlatmayan bir tiyatro formu olan Bedensel Mim'e borçlu olmakla birlikte, yarattığı karakter, daha çok, ünlü 19. Yüzyıl pantomim karakteri Jean-Gaspard Deburau'dan esinlenir. Böylece Marceau formun yaygınlaştırımasına olduğu kadar, ne yazık ki yanlış anlaşılmasına da katkıda bulunmuştur. 19 yüzyıl pandomiminin aksine Bedensel Mim'de hareketler sözlerin yerini almak istemez. Decroux'nun bedensel dili sadece yaşamın dil-öncesi, dil-sonrası ve dil kullanımayan alanlarıyla ilgilenmiştir. "Tiyatroya yabancı sanatlar" olarak adlandırdığı resim, heykel, müzik, dans ve edebiyatı, oyuncunun 
bedensel ifade olanaklarını yetkinleştirmek üzere ve sadece bir süreliğine yasaklar. Işık, kostüm, makyaj ya da "illüzyon" yaratan diğer tüm yardımcı öğelerin yardımını reddeden oyuncu, kendi bedenin sınırlarında, yerçekimine karşı mücadele ederek dramatik anı yaratır. Decroux'nun okulunda yetişen çok sayıda oyuncunun bugün oyuncu merkezli "performing arts" alanında üretim yapması tesadüf değildir.

Aşağıdaki metin Thomas Leabhart'ın son oyunu "Bonjour Monsieur Decroux"nun metni ve Thomas Leabhart'ın tanık olduğu biçimiyle olduğu Decroux'nun dünyasını anlatıyor. Metin, oyun sırasında sahnenin yan tarafında oturan bir oyuncu tarafından okunuyor. Bu oyun Nisan 2005'te, 14. ISTA ${ }^{1}$ toplantısında Wraslaw'daki Grotowski Merkezi'nde sergilendi.

1968-1972 yıllarında Etienne Decroux'nun öğrencisi ve asistanı olan ve 1988 yılına kadar Decroux ile çalışmalarını sürdüren oyuncu, yönetmen, editör ve öğretim üyesi Thomas Leabhart, bugün Bedensel Mim'in dünyadaki en önemli temsilcilerinden biridir.

$$
\text { बैซือ }
$$

